Jurnal Fokus Manajemen Bisnis
Vol.11, No. 1, Maret 2021, pp. 42-63
https://doi.org/10.12928//fokus.v11i1.3234
http://journal2.uad.ac.id/index.php/fokus
$\begin{aligned} & \text { Universitas } \\ & \text { Ahmad Dahlan }\end{aligned}$

\title{
ANALISIS PERBEDAAN HARGA SAHAM, RETURN SAHAM, DAN ABNORMAL RETURN SEBELUM DAN SESUDAH STOCK SPLIT PADA PERUSAHAAN HIGH PROFILE DAN LOW PROFILE YANG TERDAFTAR DI BURSA EFEK INDONESIA
}

\author{
Pita Rahmawati ${ }^{1}$, Jawoto Nusantoro ${ }^{2,}{ }^{,}$, Gustin Padwa Sari ${ }^{3}$ \\ Universitas Muhammadiyah Metro \\ pakjawoto@yahoo.co.id \\ *Jawoto Nusantoro
}

Article history

Received 2020-12-16

Revised 2021-03-22

Accepted 2021-03-22

Keywords

Stock Split

Stock Prices

Stock Returns

Abnormal Return

This research aims to determine whether there are differences in stock prices, stock returns and abnormal returns before and after a stock split in high profile and low profile companies. The research period used in this study was on 2016-2018. The research was analyzed in quantitative method by using a purposive sampling method. Based on the sampling criteria, 40 companies were selected as research samples. Kolmogorov Smirnov One Sample test was used for the normality test. After the normality test was carried out, the data was processed using the two paired-sample difference test. The t-test (paired sample t-test) was used if data were normally distributed but if it was not normally distributed the Wilcoxon Signed Rank test would be used. Hypothesis testing results showed that (1) there are differences in stock prices whether before and after a stock split in high profile companies (2) there are differences in stock prices whether before and after the stock split in low profile companies (3) there are differences in stock returns whether before and after a stock split in the company high profile (4) there is no difference in stock returns whether before and after the stock split in low profile companies (5) there is no difference in abnormal returns whether before and after the stock split in high profile companies (6) there is no difference in abnormal returns whether before and after the stock split in low profile companies (7) there are differences in stock prices after a stock split in high profile companies and low profile (8) there is no difference in stock returns whether before and after the stock split in high profile and low profile companies (9) there is no difference in abnormal stock returns whether before and after a stock split at high profile and low profile companies.

This is an open-access article under the CC-BY-SA license.

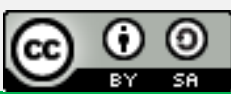

\section{Pendahuluan}

Pada zaman modern ini pasar modal di Indonesia semakin berkembang seiring dengan fungsinya yang semakin vital sebagai instrumen penting dalam perkembangan sistem perekonomian. Sebagai penghimpun dana dan lembaga investasi, pasar modal mempunyai hubungan erat dengan investor selaku pihak yang berinvestasi. Hal tersebut dibuktikan dengan penelitian yang dilakukan oleh Budiyanti (2011) bahwa pasar modal memiliki pengaruh besar terhadap pertumbuhan ekonomi di Indonesia. Banyak investor yang tertarik melakukan investasi saham pada perusahaan yang sudah go public, tapi dalam memutuskan suatu portofolio perusahaan yang layak, para investor memerlukan informasi yang memadai 
untuk menentukan perusahaan mana yang akan memberikan return paling tinggi untuk mereka (Hanafie dan Diyani, 2016). Oleh karena itu, investor harus mengetahui infomasi terkait dengan perkembangan pasar modal untuk mengambil pertimbangan dan keputusan dalam berinvestasi.

Salah satu informasi yang penting untuk diperhatikan oleh investor adalah peristiwa pemecahan saham (stock split). Alasan umum perusahaan melakukan stock split agar harga sahamnya tidak terlalu tinggi, sehingga hal ini akan meningkatkan likuiditas perdagangan (Jogiyanto, 2017). Likuiditas suatu sekuritas merupakan cepat lambatnya sekuritas tersebut dapat diperjualbelikan. Pada saat reaksi pasar terhadap saham perusahaan meningkat, maka akan meningkatkan harga saham perusahaan dimana akan mendatangkan return kepada perusahaan maupun investor dan juga memberikan abnormal return, ketika harga saham perusahaan semakin meningkat maka meningkatkan return saham perusahaan sehingga melebihi return pasar (Hanafi dan Lucia, 2016).

Perusahaan yang memiliki saham dengan harga tinggi memberikan sinyal bahwa perusahaan tersebut memiliki prospek masa depan yang baik, dimana harga saham yang tinggi mencerminkan bahwa perusahaan memiliki kinerja yang baik (Damayanti et al., 2014). Menurut trading range theory harga saham yang terlalu tinggi menyebabkan saham menjadi tidak likuid. Hal tersebut berkaitan dengan kemampuan tiap-tiap investor yang berbeda. Hubungan stock split dengan trading range theory dapat dilihat dari sudut pandang internal perusahaan yang memotivasi perusahaan untuk melakukan pemecahan saham yang dapat dilihat dari keuntungan di masa yang akan datang bagi perusahaan (Damayanti et al., 2014).

Semakin meningkat permintaan dan penawaran suatu saham, maka akan berpengaruh besar terhadap kenaikan harga saham di bursa saham. Sedangkan semakin meningkatnya volume perdagangan saham menandakan bahwa saham tersebut semakin diminati oleh publik sehingga akan membawa pengaruh terhadap naik turunnya harga atau return saham tersebut (Susianti, 2020). Likuiditas perdagangan saham juga akan mempengaruhi besarnya return saham yang akan diperoleh. Return saham merupakan hasil yang diperoleh dari investasi dalam bentuk saham (Jogiyanto, 2017).

Pemecahan saham yang dilakukan oleh perusahaan akan dinilai oleh investor sebagai sinyal bahwa manajer memiliki sinyal yang menguntungkan bagi mereka, di mana hal tersebut ditunjukkan dengan adanya perkiraan abnormal return yang bernilai positif di sekitar pengumuman stock split. Hal ini diartikan bahwa hanya perusahaan yang memiliki kinerja baik yang dapat memberikan sinyal yang akan dapat dipercaya oleh investor (Ijak, 2018). Sedikitnya transaksi perdagangan yang terjadi akan menyebabkan harga bergerak tidak konsisten sehingga harapan untuk mendapatkan abnormal return semakin sedikit. Abnormal return merupakan kelebihan dari return yang sesungguhnya terjadi terhadap return normal. Return normal merupakan return ekspektasian (return yang diharapkan oleh investor). Dengan demikian abnormal return adalah selisih diantara return yang sebenarnya dengan return yang diharapkan investor (Jogiyanto, 2017). Abnormal return yang positif menunjukkan bahwa return yang diterima lebih besar dari yang diharapkan, jika return yang diterima itu lebih kecil dari yang diharapkan, maka disebut abnormal return negatif atau return tidak sesuai harapan investor.

Indarti dan Purba (2011) menyatakan bahwa terdapat perbedaan rata-rata harga saham yang signifikan pada periode sebelum dan sesudah pengumuman pemecahan saham. Hasil tersebut menunjukkan bahwa pada peristiwa pemecahan saham di Indonesia, trading range theory yang menyatakan bahwa setelah pengumuman pemecahan saham, harga saham berubah secara signifikan, yaitu berada pada optimal trading range terjadi. Serta terdapat perbedaan yang signifikan antara volume perdagangan sebelum dan sesudah peristiwa pemecahan saham. Berbeda dengan penelitian Kristianiarso (2016) dan Prisillia (2017) bahwa tidak ada perbedaan yang signifikan antara harga saham dan volume perdagangan

Pita Rahmawati et al., (Analisis Perbedaan Harga Saham, Return Saham, dan Abnormal Return

Sebelum dan Sesudah Stock Split pada Perusahaan High Profile dan Low Profile yang Terdaftar di 
saham sebelum dan sesudah stock split. Hal tersebut membuktikan bahwa terdapat perbedaan yang signifikan antara return saham sebelum dan sesudah stock split.

Penelitian Hanafie dan Diyani (2016) menyatakan bahwa tidak terdapat perbedaan yang signifikan pada return saham sebelum dan sesudah pengumuman stock split. Berbeda dengan penelitian yang telah dilakukan Kristianiarso (2016) yang menunjukkan bahwa terdapat perbedaan signifikan return saham antara sebelum dan sesudah stock split. Hal ini berarti bahwa pengumuman stock split tersebut memberikan pengaruh positif investor terhadap return saham serta memberikan sinyal positif untuk mempengaruhi investor dalam pengambilan keputusan investasinya.

Penelitian Satria dan Adnan (2018) menunjukkan bahwa tidak terdapat perbedaan abnormal return sebelum dan sesudah peristiwa stock split. Hal ini terjadi karena investor masih ragu-ragu dengan return yang akan diperoleh dari perusahaan yang melakukan stock split. Namun penelitian Sakti dan Pangestuti (2013) dan Sadikin (2016) terdapat perbedaan yang signifikan pada abnormal return sebelum dan sesudah stock split pada perusahaan tidak bertumbuh. Hal ini menunjukkan bahwa aktifitas stock split yang dilakukan perusahaan go public berpengaruh terhadap pengambilan keputusan.

Berdasarkan penelitian terdahulu, peneliti memutuskan dalam penelitian ini menentukan variabel-variabel yang dapat berpengaruh terhadap stock split. Variabel tersebut antara lain harga saham, return saham, dan abnormal return. Dalam hal ini, penelitian mengambil sampel berdasarkan tipe perusahaan high profile dan low profile go public yang terdapat di Bursa Efek Indonesia. Urmila dan Mertha (2017) menjelaskan terdapat dua macam tipe perusahaan yaitu high profile dan low profile. Perusahaan yang tergolong high profile biasanya mendapatkan banyak perhatian atau sorotan dari masyarakat luas karena memiliki tingkat kompetisi yang ketat, tingkat resiko politik yang tinggi dan memiliki tingkat sensitivitas terhadap lingkungan yang tinggi.

Di sisi lain industri low profile adalah perusahaan yang tidak terlalu mendapatkan banyak perhatian atau sorotan dari masyarakat luas karena industri ini memiliki tingkat consumer visibility, tingkat risiko politik, dan tingkat kompetensi yang rendah. Perusahaanperusahaan yang termasuk dalam industri yang high profile lebih banyak diawasi oleh pemerintah dibandingkan perusahaan yang termasuk dalam industri yang low profile (Sari, 2012). Penelitian ini ingin melihat lebih jauh apakah terdapat perbedaan harga saham, return saham, dan abnormal return sebelum dan sesudah stock split pada perusahaan high profile dan low profile.

Industri yang termasuk dalam perusahaan berkategori high profile antara lain perusahaan otomotif, penerbangan, pertanian, rokok dan tembakau, makanan dan minuman, media komunikasi, energi (listrik), kesehatan, dan transportasi. Sedangkan perusahaan yang termasuk tipe low profile antara lain perusahaan bangunan, keuangan dan perbankan, penyedia alat medis, properti, retailer, tekstil, produk personal, dan produk rumah tangga (Yulia dan Afrianti, 2014).

\section{Review Literatur dan Hipotesis}

\subsection{Landasan Teori}

\subsubsection{Harga Saham}

Harga saham sering dijadikan cerminan kinerja dari sebuah perusahaan. Perusahaan dengan harga saham yang terus meningkat dinilai oleh investor memiliki kinerja yang baik, sehingga menarik minat mereka untuk membeli saham perusahaan tersebut. Harga saham yang dimaksud adalah harga dimana saham tersebut diperjualbelikan di pasar saham. Jogiyanto (2017) mendefinisikan harga saham sebagai harga dari saham di pasar bursa yang ditentukan oleh pelaku pasar berdasarkan permintaan dan penawaran saham yang bersangkutan di pasar bursa. Semakin banyak permintaan investor akan sebuah saham maka harga saham tersebut akan terus naik, 
begitu juga sebaliknya.

\subsubsection{Return Saham}

Menurut Jogiyanto (2017) return saham merupakan hasil yang diperoleh dari investasi dalam bentuk saham. Return dapat berupa return realisasi yang sudah terjadi atau return ekspektasi yang belum terjadi tetapi yang diharapkan terjadi dimasa yang akan datang. Return realisasi (actual return) merupakan return yang telah terjadi. Return realisasi dihitung berdasarkan data historis. Return realisasi penting karena digunakan sebagai salah satu pengukur kinerja dari perusahaan. Return historis ini juga berguna sebagai dasar penentuan ekspektasi (expected return) dan risiko dimasa mendatang. Return ekspektasi (expected return) adalah return yang diharapkan akan diperoleh oleh investor dimasa mendatang. Berbeda dengan return realisasi yang sifatnya sudah terjadi, return ekspektasi sifatnya belum terjadi.

\subsubsection{Abnormal Return}

Abnormal return atau excess return merupakan kelebihan return yang sesungguhnya terjadi terhadap return normal. Return normal merupakan return expectations (return yang diharapkan oleh investor). Dengan demikian return tak normal (abnormal return) adalah selisih antara return sesungguhnya yang terjadi dengan return expectations (Jogiyanto, 2017). Menurut Wijanarko dan Prasetiono (2012) abnormal return yang positif menunjukkan bahwa return yang diterima lebih besar dari return yang diharapkan, sebaliknya jika return yang diterima itu lebih kecil daripada yang diharapkan maka disebut abnormal return negatif. Sedangkan menurut Utami dan Ulupui (2013) abnormal return ini dapat digunakan sebagai alat untuk mengukur apakah terjadi reaksi pasar terhadap suatu pengumuman atau event yang dipublikasikan di pasar modal.

\subsubsection{Event Study}

Studi peristiwa (event study) merupakan studi yang mempelajari reaksi pasar terhadap suatu peristiwa (event) yang informasinya dipublikasikan sebagai suatu pengumuman. Event study dapat digunakan untuk menguji kandungan informasi (information content) dari suatu pengumuman dan dapat juga digunakan untuk menguji efisiensi pasar bentuk setengah kuat. Pengujian kandungan informasi dan pengujian efisiensi pasar bentuk setengah kuat merupakan dua pengujian yang berbeda. Pengujian kandungan informasi dimaksudkan untuk melihat reaksi dari suatu pengumuman. Jika pengumuman mengandung informasi (information content), maka diharapkan pasar akan bereaksi pada waktu pengumuman tersebut diterima oleh pasar.

\subsubsection{Stock Split}

Menurut Jogiyanto (2017) stock split adalah memecah selembar menjadi $n$ lembar saham. Harga saham baru setelah stock split adalah $1 / \mathrm{n}$ dari harga sebelumnya. Menurut Kohsaka (2014) stock split membagi saham baru untuk pemegang saham yang ada dalam proporsi kepemilikan mereka saat ini yang nantinya akan meningkatkan jumlah saham yang beredar.

\subsection{Hipotesis}

\subsubsection{Pengaruh Stock Split pada Harga Saham Perusahaan High Profile}

Harga saham merupakan salah satu hal yang diperhatikan oleh investor, jika harga saham suatu perusahaan dinilai terlalu tinggi, maka investor merasa kurang

Pita Rahmawati et al., (Analisis Perbedaan Harga Saham, Return Saham, dan Abnormal Return

Sebelum dan Sesudah Stock Split pada Perusahaan High Profile dan Low Profile yang Terdaftar di 
tertarik untuk membeli saham terutama investor dengan modal kecil. Hal ini menyebabkan para investor memilih untuk beralih pada saham perusahaan lain. Untuk menghindari kondisi tersebut, maka perusahaan dapat melakukan corporate action berupa stock split untuk menempatkan harga sahamnya pada rentang harga tertentu yang dapat menarik minat investor. Alasan umum perusahaan melakukan stock split agar harga sahamnya tidak terlalu tinggi, sehingga dengan harga saham yang tidak terlalu tinggi akan meningkatkan likuiditas perdagangan.

Perbedaan harga saham sebelum dan sesudah stock split pada perusahaan high profile tersebut menunjukkan bahwa harga saham di Bursa Efek Indonesia mencerminkan secara cepat dan akurat semua informasi yang dipublikasikan, termasuk informasi stock split dilakukan oleh perusahaan high profile. Hasil penelitian ini juga sesuai dengan penelitian yang dilakukan oleh Indarti dan Purba (2011) serta Satria dan Adnan (2018). Berdasarkan trading range theory, kenaikan harga saham setelah pengumuman stock split kemungkinan dikarenakan harga saham yang lebih rendah dari sebelumnya, sehingga permintaan pada saham tersebut meningkat karena daya beli terhadap saham tersebut naik. Hal tersebut diikuti dengan likuiditas saham yang meningkat dan mengakibatkan harga saham juga meningkat. Perubahan harga saham diukur dengan membandingkan rata-rata harga saham periode tertentu, setelah itu rata-rata harga saham sebelum stock split dibandingkan dengan rata-rata harga saham sesudah stock split. Apabila terdapat perbedaan yang signifikan, berarti stock split berpengaruh terhadap harga saham. Berdasarkan penjelasan tersebut dapat dirumuskan hipotesis sebagai berikut:

$\mathrm{H}_{1}$ : Terdapat Perbedaan Harga Saham Sebelum dan Sesudah Stock Split pada Perusahaan High Profile.

\subsubsection{Pengaruh Stock Split pada Harga Saham Perusahaan Low Profile}

Harga saham merupakan nilai suatu saham yang mencerminkan kekayaan perusahaan yang mengeluarkan saham tersebut. Harga saham terbentuk dari interaksi penjual dan pembeli saham di pasar modal atau bursa efek yang dilatarbelakangi oleh harapan mereka terhadap keuntungan perusahaan. Dengan asumsi adanya sinyal informasi yang dibawa stock split, berdampak pada perusahaan low profile yang merupakan perusahaan yang kurang mendapatkan perhatian masyarakat pun memanfaatkan fenomena stock split ini, untuk menarik minat investor dan meningkatkan harga saham (Rahayu, 2006). Berdasarkan penjelasan tersebut dapat dirumuskan hipotesis sebagai berikut:

\section{$\mathrm{H}_{2}$ : Terdapat Perbedaan Harga Saham Sebelum dan Sesudah Stock Split pada Perusahaan Low Profile.}

\subsubsection{Pengaruh Stock Split pada Return Saham Perusahaan High Profile}

Perusahaan yang melakukan stock split biasanya adalah perusahaan-perusahaan besar yang mempunyai harga saham yang tinggi. Untuk menjaga likuiditas sahamnya perusahaan melakukan kebijakan stock split, yang menyebabkan harga saham menjadi rendah karena pemecahan. Hal ini akan menimbulkan suatu reaksi pasar yang positif meskipun nilai dari saham tersebut tidak berubah secara ekonomi tetapi investor akan tertarik dalam menginvestasikan dananya ke perusahaan dengan harapan akan mendapatkan return dari informasi stock split tersebut. Return merupakan hasil yang diperoleh dari hasil investasi, return juga merupakan salah satu faktor yang memotivasi investor untuk melakukan investasi dengan tingkat risiko tertentu.

Investor selalu mengharapkan tingkat return yang sesuai atas suatu risiko investasi yang dihadapi. Dalam hal ini perusahaan high profile melakukan kebijakan stock spilt, untuk mengetahui apakah mengalami perbedaan penurunan baik pada 
volume perdagangan saham maupun return saham Rusliati dan Farida (2010). Hasil penelitian Berdasarkan penjelasan tersebut dapat dirumuskan hipotesis sebagai berikut:

H$_{3}$ : Terdapat Perbedaan Return Saham Sebelum dan Sesudah Stock Split pada Perusahaan High Profile.

\subsubsection{Pengaruh Stock Split pada Return Saham Perusahaan Low Profile}

Reaksi pasar yang ditimbulkan akibat stock split pada perusahaan low profile berbeda dengan perusahaan high profile. Stock split yang dilakukan perusahaan low profile akan ditangkap sebagai sinyal negatif dikarenakan kurangnya kepercayaan investor terhadap prospek perusahaan dimasa yang akan datang. Rusliati dan Farida (2010) menjelaskan bahwa terdapat penurunan baik pada volume perdagangan saham maupun return saham, sehingga pemecahan saham berpengaruh signifikan terhadap return saham dan volume perdagangan saham. Berdasarkan penjelasan tersebut dapat dirumuskan hipotesis sebagai berikut:

H$_{4}$ : Terdapat Perbedaan Return Saham Sebelum dan Sesudah Stock Split pada Perusahaan Low Profile.

\subsubsection{Pengaruh Stock Split pada Abnormal Return Saham Perusahaan High Profile}

Terdapatnya perubahan abnormal return sebelum dan sesudah stock split dapat dijadikan sebagai indikator dari sinyal positif yang dibawa kepada pasar. Signaling theory menyatakan bahwa stock split memberikan informasi kepada investor tentang peningkatan return masa depan yang substansial. Jadi, apabila pasar bereaksi terhadap pengumuman stock split, reaksi ini tidak semata-mata karena informasi stock split yang tidak mempunyai nilai ekonomis tetapi karena mengetahui prospek masa depan yang bersangkutan. Alasan sinyal ini didukung dengan adanya kenyataan bahwa perusahaan yang melakukan stock split adalah perusahaan yang memiliki kinerja yang baik.

Dalam teori efisiensi pasar bila pemecahan saham mengandung informasi maka pasar akan bereaksi. Reaksi pasar dapat dilihat dari abnormal return yang diperoleh investor maka pemecahan saham berpengaruh signifikan positif terhadap abnormal return (Adilah dan Nuzula, 2017). Sebaliknya jika pemecahan saham tidak mengandung informasi, maka pasar tidak akan bereaksi sehingga tidak terdapat abnormal return. Berdasarkan penjelasan tersebut dapat dirumuskan hipotesis sebagai berikut:

$\mathrm{H}_{5}$ : Terdapat Perbedaan Abnormal Return Saham Sebelum dan Sesudah Stock Split pada Perusahaan High Profile.

\subsubsection{Pengaruh Stock Split pada Abnormal Return Saham Perusahaan Low Profile}

Suatu informasi dapat dikatakan mempunyai nilai guna bagi investor, apabila informasi tersebut memberikan reaksi untuk melakukan transaksi di pasar modal. Begitupun halnya dengan signalling theory pada stock split. Pasar yang efisien dapat menjangkau, menangkap, dan merespon informasi- informasi yang ada di pasar modal. Selisih return saham yang bisa didapatkan dengan memanfaatkan informasi yang tersedia, menunjukkan pasar yang efisien berbentuk kuat. Reaksi pasar dapat dilihat dari abnormal return yang diperoleh investor maka dapat disimpulkan bahwa pemecahan saham berpengaruh signifikan positif terhadap abnormal return saham (Kurniawati, 2003). Berdasarkan penjelasan tersebut dapat dirumuskan hipotesis sebagai berikut:

$\mathrm{H}_{6}$ : Terdapat Perbedaan Abnormal Return Saham Sebelum dan Sesudah Stock Split pada Perusahaan Low Profile.

Pita Rahmawati et al., (Analisis Perbedaan Harga Saham, Return Saham, dan Abnormal Return

Sebelum dan Sesudah Stock Split pada Perusahaan High Profile dan Low Profile yang Terdaftar di 


\subsubsection{Perbedaan Harga Saham Sesudah Stock Split antara Perusahaan High Profile dan Low Profile}

Dampak positif kebijakan stock split ditandai dengan banyaknya investor yang tertarik untuk membeli saham tersebut sehingga harga saham meningkat dan akhirnya tujuan perusahaan untuk mensejahterakan para pemegang saham tercapai. Dampak stock split yang ada karena informasi yang terkandung di dalamnya pasti memiliki pengaruh berbeda terhadap masing-masing tipe perusahaan (Azizah, 2019). Dengan demikian, dirumuskan hipotesis sebagai berikut:

$\mathrm{H}_{7}$ : Terdapat Perbedaan Harga Saham Sesudah Stock Split antara Perusahaan High Profile dan Low Profile.

\subsubsection{Perbedaan Return Saham Sesudah Stock Split pada Perusahaan High Profile} dan Low Profile

Return saham merupakan hasil atau keuntungan yang diperoleh pemegang saham sebagai hasil dari investasinya. Tanpa adanya tingkat keuntungan yang dinikmati dari suatu investasi, tentunya investor tidak akan melakukan investasi, maka setiap investasi baik jangka pendek maupun jangka panjang mempunyai tujuan utama mendapatkan keuntungan baik secara langsung atau tidak langsung. Bila prospek perusahaan membaik, maka harga saham tersebut akan meningkat. Dengan kenaikan harga saham tersebut maka diharapkan return saham juga akan mengalami kenaikan. Maka dengan peristiwa stock split dapat dilihat dan dibedakan bagaimana dampak dan pengaruh yang terjadi pada perusahaan yang termasuk tipe high profile dan low profile (Shofa dan Utiyati, 2016). Dengan demikian, dirumuskan hipotesis sebagai berikut:

$\mathrm{H}_{8}$ : Terdapat Perbedaan Return Saham Sesudah Stock Split antara Perusahaan High Profile dan Low Profile.

\subsubsection{Perbedaan Abnormal Return Saham Antara Perusahaan High Profile dan Low Profile Sesudah Stock Split}

Reaksi pasar yang terjadi sering ditinjau dari adanya abnormal return yang diperoleh oleh investor atas pemanfaatan informasi yang ada di pasar. Abnormal return bernilai positif menunjukkan bahwa return sesungguhnya atau return yang terjadi lebih besar dari return yang diharapkan oleh investor Hayat (2008), Royana (2008), dan Diyana (2008). Semakin besar abnormal return yang diberikan oleh perusahaan memperlihatkan bahwa harga saham perusahaan terus mengalami kenaikan sehingga memperoleh actual return yang lebih besar dari return yang diharapkan investor. Perusahaan yang mengumumkan stock split akan menimbulkan reaksi pasar yang berbeda pada perusahaan high profile dan low profile. Dengan demikian, dirumuskan hipotesis sebagai berikut:

H9: Terdapat Perbedaan Abnormal Return Saham Sesudah Stock Split antara Perusahaan High Profile dan Low Profile. 


\subsection{Model Penelitian}

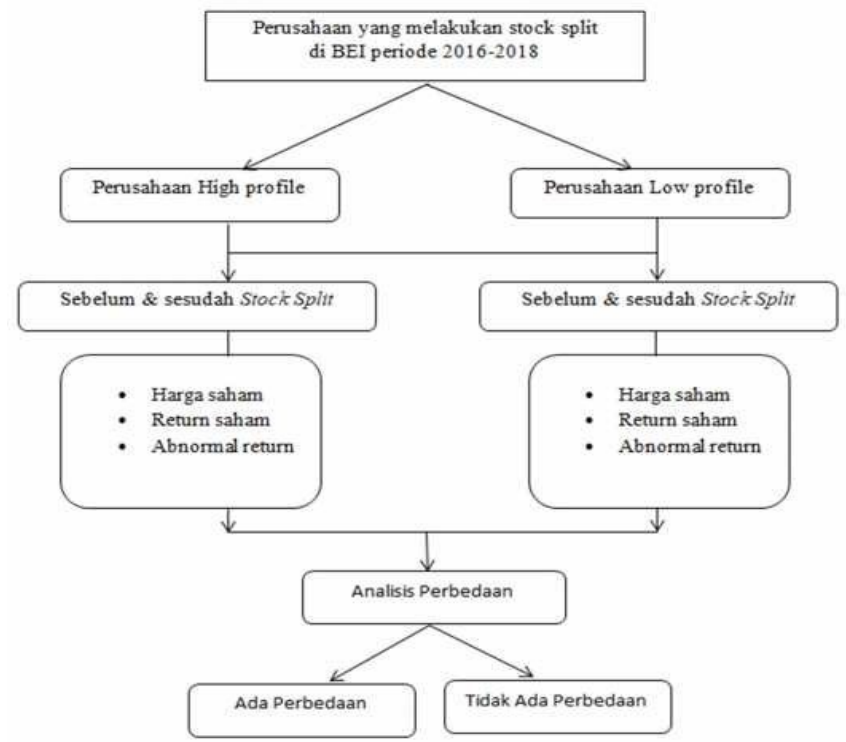

Gambar 1. Model Penelitian

\section{Metode Penelitian}

\subsection{Populasi dan Sampel}

Populasi adalah wilayah generalisasi yang terdiri atas objek atau subjek yang mempunyai kualitas dan karakteristik tertentu yang ditetapkan oleh peneliti untuk dipelajari dan kemudian ditarik kesimpulannya (Sugiyono, 2013). Populasi yang digunakan dalam penelitian ini adalah seluruh perusahaan yang terdaftar Bursa Efek Indonesia dan melakukan stock split selama periode tahun 2016-2018.

Sampel adalah bagian dari jumlah dan karakteristik yang dimiliki oleh populasi tersebut (Sugiyono, 2013). Pengukuran sampel merupakan langkah-langkah untuk menentukan besarnya sampel yang akan diambil dalam melaksanakan suatu penelitian. Selain itu juga perlu diperhatikan bahwa sampel yang dipilih harus representatif, artinya segala karakteristik populasi hendaknya tercermin dalam sampel yang dipilih. Pengambilan sampel harus dilakukan sedemikian rupa sehingga sampel yang benar- benar dapat mewakili dan dapat menggambarkan populasi sebenarnya.

Kriteria pemilihan sampel adalah sebagai berikut:

1. Perusahaan yang terdaftar di Bursa Efek Indonesia pada rentang periode tahun 20162018.

2. Mengklasifikasikan atau mengkategorikan terlebih dahulu perusahaan berdasarkan tipe high profile dan low profile.

3. Selama masa pengamatan perusahaan tidak melakukan corporate action lain selain stock split agar bisa dilihat pergerakan saham murni karena adanya stock split.

4. Sampel saham yang dipilih aktif diperdagangkan minimal 10 hari seputar pemecahan saham dengan asumsi bahwa investor benar-benar melakukan perdagangan saham murni karena melihat informasi pemecahan saham hanya 5 hari sebelum dan 5 hari sesudah.

\subsection{Teknik Analisis Data}

\subsubsection{Uji Normalitas}

Sebelum melakukan uji hipotesis terlebih dahulu dilakukan uji normalitas data untuk menentukan jenis statistik yang akan digunakan apakah statistik parametrik atau

Pita Rahmawati et al., (Analisis Perbedaan Harga Saham, Return Saham, dan Abnormal Return Sebelum dan Sesudah Stock Split pada Perusahaan High Profile dan Low Profile yang Terdaftar di 
statistik nonparametrik (Sugiyono, 2013). Uji normalitas bertujuan untuk menguji apakah dalam sebuah model regresi, variabel dependen memiliki distribusi normal atau tidak. Model regresi yang baik adalah data normal atau mendekati normal. Caranya adalah dengan normal probability plot yang membandingkan distribusi kumulatif dari distribusi normal. Data yang normal atau mendekati distribusi normal memiliki bentuk seperti lonceng.

Untuk menguji normalitas data, model regresi dapat dideteksi dengan melihat penyebaran data (titik) pada sumbu diagonal dari grafik atau dengan melihat histrogram dari residualnya. Data dapat dikatakan normal bila data atau titik-titik tersebar di sekitar grafis diagonal dan penyebarannya mengikuti grafis diagonal atau grafik histrogramnya. Jika data penyebaran di sekitar garis diagonal dan mengikuti arah garis diagonal, maka regresi memenuhi asumsi normalitas. Namun, jika data menyebar dari garis diagonal dan atau tidak mengikuti arah garis diagonal, maka regresi tidak memenuhi asumsi normalitas (Ghozali, 2013).

Metode yang lebih akurat untuk menguji normalitas adalah dengan uji Kolmogorov-smirnov, yaitu dengan melihat angka profitabilitas signifikan, yaitu:

1. Jika (Asymp Sig) $<0,05$ maka distribusi data tidak normal

2. Jika (Asymp Sig) > 0,05 maka distribusi data normal

Setelah uji normalitas dilakukan selanjutnya data diolah menggunakan uji beda dua sampel berpasangan dengan ketentuan sebagai berikut:

1. Apabila data berdistribusi normal digunakan uji t (paired sample t-test)

2. Apabila data berdistribusi tidak normal digunakan uji wilcoxon signed rank test (uji non parametrik)

\subsubsection{Uji Hipotesis}

Variabel independen kuantitatif dalam penelitian ini memiliki dua kategori, oleh sebab itu dilakukan pengujian dengan metode uji beda rata-rata untuk dua sampel berpasangan (uji paired $t$-test). Metode uji beda ini digunakan untuk menganalisi model penelitian pre-post atau sebelum sesudah. Uji beda ini mengevaluasi perlakuan tertentu pada suatu sampel yang sama pada dua periode pengamatan yang berbeda (Azizah, 2019). Paired sampel t-test digunakan apabila data berdistribusi normal.

Untuk pengambilan keputusan perlu beberapa pertimbangan yang harus dilakukan, yaitu:

1. Jika probabilitas $<0,05$, maka hipotesis ditolak artinya tidak terdapat perbedaan varians.

2. Jika probabilitas $>0,05$, maka hipotesis tidak ditolak artinya terdapat kesamaan varians.

Menurut Ghozali (2013) standard error perbedaan dalam nilai rata- rata harus terdistribusi normal. Berdasarkan hasil tersebut maka penelitian akan menggunakan uji normalitas kolmogorov-smirnov. Begitu juga sebaliknya, jika data tidak terdistribusi dengan normal, maka digunakan uji non parametric yaitu uji rank Wilcoxon. 
4. Hasil dan Pembahasan

\subsection{Uji Normalitas}

Tabel 1. Hasil Analisis Data Harga Saham Perusahaan High Profile

\begin{tabular}{cccc}
\hline & & Sebelum & Sesudah \\
\hline \multirow{2}{*}{ Normal Paramaters } & Mean & 80 & 80 \\
& Std. Deviation & 14891,71 & 1732,69 \\
Most Extreme & Absolute & 24051,878 & 2359,473 \\
Differences & Positive & 0,298 & 0,275 \\
& Negative & 0,298 & 0,275 \\
Test Statistic & $-0,271$ & $-0,247$ \\
Asymp. Sig. (2-Tailed) & 0,298 & 0,275 \\
& & 0,000 & 0,000 \\
\hline
\end{tabular}

Tabel 1 di atas menunjukkan bahwa data tersebut tidak berdistribusi normal karena menunjukkan nilai signifikan kurang dari 0,05 yaitu 0,000 baik sebelum maupun sesudah stock split pada perusahaan high profile.

Tabel 2. Hasil Analisis Data Harga Saham Perusahaan Low Profile

\begin{tabular}{cccc}
\hline & & Sebelum & Sesudah \\
\hline \multirow{2}{*}{ Normal Paramaters } & Mean & 120 & 120 \\
& Std. Deviation & 3834,39 & 959,91 \\
Most Extreme & Absolute & 4590,028 & 1543,178 \\
Differences & Positive & 0,299 & 0,367 \\
& Negative & 0,299 & 0,367 \\
Test Statistic & $-0,221$ & $-0,300$ \\
Asymp. Sig. (2-Tailed) & 0,299 & 0,367 \\
& 0,000 & 0,000 \\
\hline
\end{tabular}

Tabel 2 di atas menunjukkan bahwa data tersebut tidak berdistribusi normal karena menunjukkan nilai signifikan kurang dari 0,05 yaitu 0,000 baik sebelum maupun sesudah stock split pada perusahaan low profile.

Tabel 3. Hasil Analisis Data Return Saham Perusahaan High Profile

\begin{tabular}{cccc}
\hline & & Sebelum & Sesudah \\
\hline \multirow{2}{*}{ Normal Paramaters } & Mean & 80 & 80 \\
& Std. Deviation & 0,010614 & $-0,010329$ \\
Most Extreme & Absolute & 0,0360056 & 0,1086300 \\
Differences & Positive & 0,259 & 0,304 \\
& Negative & $-0,213$ & 0,250 \\
Test Statistic & 0,259 & $-0,304$ \\
Asymp. Sig. (2-Tailed) & 0,000 & 0,304 \\
\end{tabular}

Tabel 3 di atas menunjukkan bahwa data tersebut tidak berdistribusi normal karena menunjukkan nilai signifikan kurang dari 0,05 yaitu 0,000 baik sebelum maupun sesudah stock split pada perusahaan high profile.

Pita Rahmawati et al., (Analisis Perbedaan Harga Saham, Return Saham, dan Abnormal Return Sebelum dan Sesudah Stock Split pada Perusahaan High Profile dan Low Profile yang Terdaftar di 
Tabel 4. Hasil Analisis Data Return Saham Perusahaan Low Profile

\begin{tabular}{cccc}
\hline & & Sebelum & Sesudah \\
\hline \multirow{2}{*}{ Normal Paramaters } & Mean & 120 & 120 \\
& Std. Deviation & 0,007233 & 0,0048671 \\
Most Extreme & Absolute & 0,0370179 & 0,05815409 \\
Differences & Positive & 0,232 & 0,226 \\
& Negative & 0,232 & 0,226 \\
Test Statistic & $-0,196$ & $-0,148$ \\
Asymp. Sig. (2-Tailed) & 0,232 & 0,226 \\
\hline
\end{tabular}

Tabel 4 di atas menunjukkan bahwa data tersebut tidak berdistribusi normal karena menunjukkan nilai signifikan kurang dari 0,05 yaitu 0,000 baik sebelum maupun sesudah stock split pada perusahaan low profile.

Tabel 5. Hasil Analisis Data Abnormal Return Perusahaan High Profile

\begin{tabular}{cccc}
\hline & & Sebelum & Sesudah \\
\hline \multirow{2}{*}{ Normal Paramaters } & Mean & 45 & 45 \\
& Std. Deviation & $-4,6742$ & $-4,2760$ \\
Most Extreme & Absolute & 1,53991 & 1,12230 \\
Differences & Positive & 0,113 & 0,087 \\
& Negative & 0,103 & 0,087 \\
Test Statistic & $-0,113$ & $-0,074$ \\
Asymp. Sig. (2-Tailed) & 0,113 & 0,087 \\
\end{tabular}

Tabel 5 di atas menunjukkan bahwa data tersebut tidak berdistribusi normal karena menunjukkan nilai signifikan lebih dari 0,05 yaitu 0,189 untuk sebelum stock split dan 0,200 untuk sesudah stock split pada perusahaan high profile.

Tabel 6. Hasil Analisis Data Abnormal Return Perusahaan Low Profile

\begin{tabular}{cccc}
\hline & & Sebelum & Sesudah \\
\hline \multirow{2}{*}{ Normal Paramaters } & & 60 & 60 \\
& Mean & $-4,3963$ & $-3,9539$ \\
Most Extreme & Std. Deviation & 1,21644 & 1,45445 \\
Differences & Absolute & 0,090 & 0,092 \\
& Positive & 0,088 & 0,054 \\
Test Statistic & Negative & $-0,090$ & $-0,092$ \\
Asymp. Sig. (2-Tailed) & 0,090 & 0,092 \\
& 0,200 & 0,200 \\
\hline
\end{tabular}

Tabel 6 di atas menunjukkan bahwa data tersebut tidak berdistribusi normal karena menunjukkan nilai signifikan lebih dari 0,05 yaitu 0,200 untuk sebelum dan sesudah stock split pada perusahaan low profile. 


\subsection{Uji Hipotesis}

Tabel 7. Hasil Analisis Data Harga Saham Perusahaan High Profile

\begin{tabular}{cc}
\hline & Sesudah-Sebelum \\
\hline Z & $-7,770$ \\
Asymp. Sig. (2-tailed) & 0,000 \\
\hline
\end{tabular}

Tabel 7 di atas menjelaskan bahwa nilai asymp. sig (2-tailed) bernilai $<0,05$ pada harga saham sebelum dan sesudah stock split di perusahaan high profile di Bursa Efek Indonesia yaitu sebesar 0,000 , maka terdapat perbedaan yang signifikan pada harga saham.

Tabel 8. Hasil Analisis Data Harga Saham Perusahaan Low Profile

\begin{tabular}{cc}
\hline & Sesudah-Sebelum \\
\hline Z & $-9,507$ \\
Asymp. Sig. (2-tailed) & 0,000 \\
\hline
\end{tabular}

Tabel 8 di atas menjelaskan bahwa nilai asymp. sig (2-tailed) bernilai $<0,05$ pada harga saham sebelum dan sesudah stock split di perusahaan low profile di Bursa Efek Indonesia yaitu sebesar 0,000 , maka terdapat perbedaan yang signifikan pada harga saham.

Tabel 9. Hasil Analisis Data Return Saham Perusahaan High Profile Sesudah-Sebelum

$\mathbf{Z}$

Asymp. Sig. (2-tailed)
$-2,523$

0,012

Tabel 9 di atas menjelaskan bahwa nilai asymp. sig (2-tailed) bernilai $<0,05$ pada return saham sebelum dan sesudah stock split di perusahaan high profile di Bursa Efek Indonesia yaitu sebesar 0,012 , maka terdapat perbedaan yang signifikan pada return saham.

Tabel 10. Hasil Analisis Data Return Saham Perusahaan Low Profile

\begin{tabular}{cc}
\hline & Sesudah-Sebelum \\
\hline $\mathbf{Z}$ & $-1,133$ \\
Asymp. Sig. (2-tailed) & 0,257 \\
\hline
\end{tabular}

Tabel 10 di atas menjelaskan bahwa nilai asymp. sig (2-tailed) bernilai > 0,05 pada return saham sebelum dan sesudah stock split di perusahaan low profile di Bursa Efek Indonesia yaitu sebesar 0,257 , maka tidak terdapat perbedaan yang signifikan pada return saham.

Tabel 11. Hasil Analisis Data Abnormal Return Perusahaan High Profile

\begin{tabular}{|c|c|c|c|c|c|c|c|c|c|}
\hline & & \multirow[b]{2}{*}{ Mean } & \multicolumn{7}{|c|}{$\begin{array}{l}90 \% \text { Confidence } \\
\text { Interval of the } \\
\text { Difference }\end{array}$} \\
\hline & & & $\begin{array}{c}\text { Std. } \\
\text { Deviation }\end{array}$ & $\begin{array}{c}\text { Std. Error } \\
\text { Mean }\end{array}$ & Lower & Upper & $\mathbf{t}$ & df & $\begin{array}{l}\text { Sig. (2- } \\
\text { tailed) }\end{array}$ \\
\hline $\begin{array}{c}\text { Pair } \\
1\end{array}$ & $\begin{array}{l}\text { Sebelum- } \\
\text { Sesudah }\end{array}$ & 0,0209575 & 0,1079687 & 0,0120713 & 0,0030698 & 0,0449848 & 1,736 & 79 & 0,086 \\
\hline
\end{tabular}

Tabel 11 di atas menjelaskan bahwa nilai asymp. sig (2-tailed) bernilai > 0,05 pada abnormal return sebelum dan sesudah stock split di perusahaan high profile di Bursa Efek

Pita Rahmawati et al., (Analisis Perbedaan Harga Saham, Return Saham, dan Abnormal Return

Sebelum dan Sesudah Stock Split pada Perusahaan High Profile dan Low Profile yang Terdaftar di 
Indonesia yaitu sebesar 0,086 , maka tidak terdapat perbedaan yang signifikan pada abnormal return saham.

Tabel 12. Hasil Analisis Data Abnormal Return Perusahaan Low Profile

\begin{tabular}{|c|c|c|c|c|c|c|c|c|c|}
\hline & & \multirow[b]{2}{*}{ Mean } & \multirow[b]{2}{*}{$\begin{array}{c}\text { Std. } \\
\text { Deviation }\end{array}$} & \multirow[b]{2}{*}{$\begin{array}{l}\text { Std. Error } \\
\text { Mean }\end{array}$} & \multicolumn{2}{|c|}{$\begin{array}{l}\text { 90\% Confidence } \\
\text { Interval of the } \\
\text { Difference }\end{array}$} & \multirow[b]{2}{*}{$\mathbf{t}$} & \multirow[b]{2}{*}{ df } & \multirow[b]{2}{*}{$\begin{array}{c}\text { Sig. } \\
(2- \\
\text { tailed }]\end{array}$} \\
\hline & & & & & Lower & Upper & & & \\
\hline $\begin{array}{c}\text { Pair } \\
1 \\
\end{array}$ & $\begin{array}{l}\text { Sebelum- } \\
\text { Sesudah }\end{array}$ & 0,0028108 & 0,0680974 & 0,0062164 & $\begin{array}{c}- \\
0,0094983 \\
\end{array}$ & 0,0151200 & 0,452 & 119 & 0,652 \\
\hline
\end{tabular}

Tabel 12 di atas menjelaskan bahwa nilai asymp. sig (2-tailed) bernilai $>0,05$ pada abnormal return sebelum dan sesudah stock split di perusahaan low profile di Bursa Efek Indonesia yaitu sebesar 0,652 , maka tidak terdapat perbedaan yang signifikan pada abnormal return saham.

Tabel 13. Hasil Analisis Data Harga Saham Sesudah Stock Split di Perusahaan High dan Low Profile

\begin{tabular}{cc}
\hline & Low-High \\
\hline Z & $-4,691$ \\
Asymp. Sig. (2-tailed) & 0,000 \\
\hline
\end{tabular}

Tabel 13 di atas menjelaskan bahwa nilai asymp. sig (2-tailed) bernilai < 0,05 pada harga saham sesudah stock split di perusahaan high dan low profile di Bursa Efek Indonesia yaitu sebesar 0,000 , maka terdapat perbedaan yang signifikan pada harga saham.

Tabel 14. Hasil Analisis Data Return Saham Sesudah Stock Split di Perusahaan High dan Low Profile

\begin{tabular}{cc}
\hline & Low-High \\
\hline Z & $-4,691$ \\
Asymp. Sig. (2-tailed) & 0,314 \\
\hline
\end{tabular}

Tabel 14 di atas menjelaskan bahwa nilai asymp. sig (2-tailed) bernilai $>0,05$ pada return saham sesudah stock split di perusahaan high dan low profile di Bursa Efek Indonesia yaitu sebesar 0,314 , maka tidak terdapat perbedaan yang signifikan pada return saham.

Tabel 15. Hasil Analisis Data Abnormal Return Saham Sesudah Stock Split di Perusahaan High dan Low Profile

\begin{tabular}{|c|c|c|c|c|c|c|c|c|c|}
\hline & & \multirow[b]{2}{*}{ Mean } & \multicolumn{7}{|c|}{$\begin{array}{l}\text { 90\% Confidence } \\
\text { Interval of the } \\
\text { Difference }\end{array}$} \\
\hline & & & $\begin{array}{c}\text { Std. } \\
\text { Deviation }\end{array}$ & $\begin{array}{c}\text { Std. Error } \\
\text { Mean }\end{array}$ & Lower & Upper & $\mathbf{t}$ & df & $\begin{array}{l}\text { Sig. (2- } \\
\text { tailed) }\end{array}$ \\
\hline $\begin{array}{c}\text { Pair } \\
1 \\
\end{array}$ & $\begin{array}{l}\text { High- } \\
\text { Low }\end{array}$ & $\begin{array}{c}- \\
0,0099925\end{array}$ & 0,1276419 & 0,0142708 & $\begin{array}{c}- \\
0,0383978 \\
\end{array}$ & 0,0184128 & $\begin{array}{c}- \\
0,700 \\
\end{array}$ & 79 & 0,486 \\
\hline
\end{tabular}

Tabel 15 di atas menjelaskan bahwa nilai asymp. sig (2-tailed) bernilai $>0,05$ pada abnormal return saham sesudah stock split di perusahaan high dan low profile di Bursa Efek Indonesia yaitu sebesar 0,486 , maka tidak terdapat perbedaan yang signifikan pada abnormal return saham. 


\subsection{Pembahasan}

\subsubsection{Harga Saham di Bursa Efek Indonesia Sebelum dan Sesudah Stock Split pada} Perusahaan High Profile

Stock split merupakan salah satu bentuk kegiatan perusahaan guna meningkatkan tingkat likuiditas saham dan bertujuan untuk dapat menarik investor dengan harapan harga saham akan meningkat. Dari hasil penelitian pada harga saham selama lima hari sebelum dan lima hari setelah stock split terhadap 16 perusahaan high profile sebagai sampel. Secara keseluruhan dapat diketahui bahwa terdapat perbedaan yang signifikan terhadap harga saham sebelum dan sesudah pemecahan saham dari tahun 2016 sampai dengan 2018. Hal ini disebabkan karena stock split memberikan sinyal yang positif dari perusahaan kepada publik, sehingga investor yang semula tidak membeli saham karena tingginya harga saham, dapat menjangkau harga saham sesudah stock split dengan nominal yang lebih rendah.

Perbedaan harga saham sebelum dan sesudah stock split pada perusahaan high profile menunjukkan bahwa harga saham di Bursa Efek Indonesia mencerminkan secara cepat dan akurat semua informasi yang dipublikasikan, termasuk informasi stock split dilakukan oleh perusahaan high profile. Hasil penelitian ini juga sesuai dengan penelitian yang dilakukan oleh Indarti dan Purba (2011) serta Satria dan Adnan (2018). Penelitian tersebut menyatakan bahwa terdapat perbedaan rata-rata harga saham yang signifikan pada periode sebelum dan sesudah pengumuman pemecahan saham. Hasil tersebut menunjukan bahwa pada peristiwa pemecahan saham di Indonesia, trading range theory yang menyatakan bahwa setelah pengumuman pemecahan saham, harga saham berubah secara signifikan, yaitu berada pada optimal trading range terjadi.

\subsubsection{Harga Saham di Bursa Efek Indonesia Sebelum dan Sesudah Stock Split pada Perusahaan Low Profile}

Stock split merupakan salah satu bentuk kegiatan perusahaan guna meningkatkan tingkat likuiditas saham dan bertujuan untuk dapat menarik investor dengan harapan harga saham akan meningkat. Dari hasil penelitian pada harga saham selama lima hari sebelum dan lima hari setelah stock split terhadap 24 perusahaan low profile sebagai sampel. Secara keseluruhan dapat diketahui bahwa terdapat perbedaan yang signifikan terhadap harga saham sebelum dan sesudah pemecahan saham. Hal ini disebabkan karena stock split memberikan sinyal yang positif dari perusahaan kepada publik.

Hasil tersebut menunjukkan bahwa karena peristiwa pemecahan saham (stock split) yang terjadi pada perusahaan low profile menyebabkan perubahan pada harga saham dari tahun 2016 sampai dengan tahun 2018. Hal ini kemungkinan terjadi karena para investor di Indonesia memberikan feedback yang cepat terhadap informasi stock split yang diterimanya dan menganggap pengumuman stock split yang diberikan perusahaan merupakan informasi yang dapat menguntungkan. Hasil penelitian ini juga sesuai dengan penelitian yang dilakukan oleh Indarti dan Purba (2011) serta Satria dan Adnan (2018). Penelitian tersebut menyatakan bahwa terdapat perbedaan rata-rata harga saham yang signifikan pada periode sebelum dan sesudah pengumuman pemecahan saham. Hasil tersebut menunjukkan bahwa pada peristiwa pemecahan saham di Indonesia, trading range theory yang menyatakan bahwa setelah pengumuman pemecahan saham, harga saham berubah secara signifikan, yaitu berada pada optimal trading range terjadi.

Pita Rahmawati et al., (Analisis Perbedaan Harga Saham, Return Saham, dan Abnormal Return Sebelum dan Sesudah Stock Split pada Perusahaan High Profile dan Low Profile yang Terdaftar di 


\subsubsection{Return Saham di Bursa Efek Indonesia Sebelum dan Sesudah Stock Split pada Perusahaan High Profile}

Dari hasil penelitian pada return saham selama lima hari sebelum dan lima hari setelah stock split terhadap 16 perusahaan high profile sebagai sampel. Secara keseluruhan dapat diketahui bahwa terdapat perbedaan yang signifikan pada return saham sebelum maupun sesudah stock split dari tahun 2016 sampai dengan 2018. Hal ini terjadi karena para investor di perusahaan high profile merespon dengan positif pengumuman stock split dan menganggap informasi tersebut adalah informasi yang menguntungkan. Maka ini berarti reaksi pasar terhadap pengumuman stock split sangat baik dan dapat merubah minat para investor untuk berinvestasi.

Hal ini sejalan dengan signalling theory karena dengan melakukan stock split perusahaan menginformasikan prospek yang baik sehingga investor tertarik untuk membeli saham tersebut. Hasil penelitian ini juga sesuai dengan penelitian yang dilakukan oleh Kristianiarso (2016). Penelitian tersebut menyatakan bahwa terdapat perbedaan yang signifikan antara return saham sebelum dan sesudah stock split serta tidak ada perbedaan yang signifikan antara volume perdagangan saham sebelum dan sesudah stock split.

\subsubsection{Return Saham di Bursa Efek Indonesia Sebelum dan Sesudah Stock Split pada Perusahaan Low Profile}

Dari hasil penelitian pada return saham selama lima hari sebelum dan lima hari setelah stock split terhadap 24 perusahaan low profile sebagai sampel. Secara keseluruhan dapat diketahui bahwa tidak terdapat perbedaan yang signifikan pada return saham sebelum maupun setelah stock split dari tahun 2016 sampai dengan 2018. Hal ini berarti para investor di perusahaan low profile menganggap pengumuman stock split merupakan hal yang kurang menguntungkan. Dapat diartikan bahwa reaksi pasar yang kurang baik dan tidak berubah minat investor dalam berinvestasi.

Sinyal informasi tentang prospek pertumbuhan perusahaan di masa yang akan datang telah diketahui prinsipal, sehingga asimetri informasi terkait informasi ini tidak terjadi hal ini menyebabkan tidak adanya penyesuaian return dalam jumlah besar. Tingkat return saham perusahaan yang melakukan pemecahan saham hanya mengalami sedikit peningkatan setelah pemecahan saham. Upaya peningkatan return belum berhasil, yang diketahui dari tingkat harga yang stabil. Belum adanya perbedaan return sebelum dan sesudah stock split yang disebabkan beberapa hal. Penyebab pertama adalah informasi telah terserap oleh pasar dan terefleksi dalam harga pasar saham, yang mana menjadi dasar perhitungan return.

Informasi yang terserap menyebabkan investor tidak melakukan pembelian dalam jumlah relatif besar yang dapat mempengaruhi harga pasar saham. Tingkat harga yang stabil menyebabkan tidak adanya perbedaan return sebelum dan sesudah pemecahan saham. Penyebab kedua adalah perusahaan yang melakukan pemecahan saham dengan tanpa didahului peningkatan tingkat return perusahaan yang luar biasa. Investor tidak melihat adanya prospek masa depan perusahaan, seperti peningkatan dividen. Hal ini menyebabkan tingkat harga stabil. Hasil penelitian ini juga sesuai dengan penelitian yang dilakukan oleh Hanafie dan Diyani (2016) serta Rahayu dan Murti (2017) yang menyatakan bahwa tidak terdapat perbedaan yang signifikan pada return saham sebelum dan sesudah pengumuman stock split. Hal ini berarti stock split tidak memiliki pengaruh signifikan terhadap perubahan harga saham. 


\subsubsection{Abnormal Return Saham di Bursa Efek Indonesia Sebelum dan Sesudah Stock Split pada Perusahaan High Profile}

Dari hasil penelitian pada abnormal return saham selama lima hari sebelum dan lima hari setelah stock split terhadap 16 perusahaan high profile sebagai sampel. Secara keseluruhan dapat diketahui bahwa tidak terdapat perbedaan yang signifikan pada abnormal return saham sebelum maupun setelah stock split dari tahun 2016 sampai dengan 2018. Tidak adanya perbedaan abnormal return saham pada sebelum dan setelah stock split menunjukkan bahwa informasi pengumuman stock split tidak dianggap sebagai good news oleh para investor. Sebagian besar investor tidak tertarik untuk membeli saham yang sudah dipecah pada perusahaan high profile.

Signalling theory tidak berlaku pada abnormal return pada perusahaan high profile yang berada di Bursa Efek Indonesia yang dijadikan sampel pada penelitian ini dari tahun 2016 hingga 2018. Tidak adanya perbedaan abnormal return saham sebelum dan sesudah stock split pada perusahaan high profile dapat diartikan bahwa pemecahan saham tidak membawa kandungan informasi atau signalling theory tentang akan adanya keuntungan dimasa yang akan datang. Signalling theory tidak selamanya berlaku dalam peristiwa pemecahan saham karena dari hasil hipotesis membuktikan bahwa tidak terdapat perbedaan abnormal return sebelum dan sesudah stock split. Bila dikaitkan dengan efisiensi pasar, maka informasi stock split dari perusahaan high profile tidak menghasilkan abnormal return sehingga termasuk dalam efisiensi pasar setengah kuat. Akibat dari pasar efisiensi setengah kuat investor tidak memperoleh keuntungan di atas normal secara konsisten dengan memanfaatkan informasi publik. Hasil penelitian ini juga sesuai dengan penelitian yang dilakukan oleh Satria dan Adnan (2018) serta Sakti dan Pangestuti (2013) yang menyatakan bahwa tidak terdapat perbedaan abnormal return sebelum dan sesudah peristiwa stock split serta pada perusahaan bertumbuh dan tidak bertumbuh tidak terdapat perbedaan abnormal return saham yang signifikan setelah pengumuman stock split.

\subsubsection{Abnormal Return Saham di Bursa Efek Indonesia Sebelum dan Sesudah Stock Split pada Perusahaan Low Profile}

Dari hasil penelitian pada abnormal return saham selama lima hari sebelum dan lima hari setelah stock split terhadap 24 perusahaan low profile sebagai sampel. Secara keseluruhan dapat diketahui bahwa tidak terdapat perbedaan yang sangat signifikan pada abnormal return saham sebelum maupun setelah stock split dari tahun 2016 sampai dengan 2018. Hal ini berarti pengumuman stock split dianggap tidak memiliki konten informasi yang penting bagi para investor pada perusahaan low profile dan pasar tidak bereaksi terhadap informasi stock split yang diberikan perusahaan, maka hal ini menyebabkan abnormal return tidak berpengaruh secara signifikan. Investor tidak memberikan reaksi positif terhadap stock split yang dilakukan oleh perusahaan low profile, investor cenderung mengabaikan informasi mengenai optimisme manajemen terhadap prospek perusahaan dimasa yang akan datang yang disinyalkan melalui stock split pada perusahaan low profile.

Signalling theory tidak berlaku bagi stock split yang dilakukan oleh perusahaan low profile. Pada kenyataannya, sebagian besar investor tidak percaya bahwa stock split yang dilakukan oleh perusahaan low profile merupakan sinyal yang diberikan oleh manajemen mengenai prospek perusahaan yang lebih baik di masa yang akan datang, sehingga investor tersebut tidak tertarik untuk membeli saham tersebut sesudah stock split. Bila dikaitkan dengan efisiensi pasar maka pengumuman stock split pada perusahaan low profile termasuk dalam pasar efisiensi setengah kuat, hal ini terbukti tidak adanya perbedaan abnormal return sebelum dan sesudah stock split pada

Pita Rahmawati et al., (Analisis Perbedaan Harga Saham, Return Saham, dan Abnormal Return

Sebelum dan Sesudah Stock Split pada Perusahaan High Profile dan Low Profile yang Terdaftar di 
perusahaan low profile. Hasil penelitian ini juga sesuai dengan penelitian yang dilakukan oleh Sakti dan Pangestuti (2013) yang menyatakan bahwa tidak terdapat perbedaan abnormal return sebelum dan sesudah peristiwa stock split serta pada perusahaan bertumbuh dan tidak bertumbuh tidak terdapat perbedaan abnormal return saham yang signifikan setelah pengumuman stock split.

\subsubsection{Harga Saham di Bursa Efek Indonesia Sesudah Stock Split pada Perusahaan High Profile dan Low Profile}

Stock split merupakan salah satu bentuk kegiatan perusahaan guna meningkatkan tingkat likuiditas saham dan bertujuan untuk dapat menarik investor dengan harapan harga saham akan meningkat. Dari hasil penelitian pada harga saham selama lima hari sebelum dan lima hari setelah stock split terhadap 16 perusahaan high profile dan 24 perusahaan low profile sebagai sampel. Secara keseluruhan dapat diketahui bahwa terdapat perbedaan yang signifikan terhadap harga saham sebelum dan sesudah pemecahan saham. Hasil tersebut menunjukkan bahwa karena peristiwa stock split yang terjadi pada perusahaan low profile menyebabkan perubahan pada harga saham dari tahun 2016 sampai dengan tahun 2018.

Hal ini kemungkinan terjadi karena para investor di Indonesia memberikan feedback yang cepat terhadap informasi stock split yang diterimanya dan menganggap pengumuman stock split yang diberikan perusahaan merupakan informasi yang dapat menguntungkan. Hasil penelitian ini juga sesuai dengan penelitian yang dilakukan oleh Indarti dan Purba (2011) serta Satria dan Adnan (2018). Penelitian tersebut menyatakan bahwa terdapat perbedaan rata-rata harga saham yang signifikan pada periode sebelum dan sesudah pengumuman pemecahan saham. Hasil tersebut menunjukkan bahwa pada peristiwa pemecahan saham di Indonesia, trading range theory yang menyatakan bahwa setelah pengumuman pemecahan saham, harga saham berubah secara signifikan, yaitu berada pada optimal trading range terjadi.

\subsubsection{Return Saham di Bursa Efek Indonesia Sesudah Stock Split pada Perusahaan High Profile dan Low Profile}

Dari hasil penelitian pada harga saham selama lima hari sebelum dan lima hari setelah stock split terhadap 16 perusahaan high profile dan 24 perusahaan low profile sebagai sampel. Secara keseluruhan dapat diketahui bahwa tidak terdapat perbedaan yang sangat signifikan pada return saham setelah stock split dari tahun 2016 sampai dengan 2018. Hal ini disebabkan karena para investor di sebagian perusahaan high profile maupun low profile menganggap pengumuman stock split merupakan hal yang kurang menguntungkan, dapat diartikan bahwa reaksi pasar yang kurang baik dan tidak berubah minat investor dalam berinvestasi. Pada sebagian perusahaan high maupun low profile yang melakukan pengumuman stock split tidak diikuti dengan pembagian dividen kepada pemegang saham.

Dividen adalah salah satu motivasi investor dalam berinvestasi. Apabila perusahaan membayar dividen dalam jumlah besar, akan mampu memotivasi para investor untuk membeli saham tersebut. Maka pada perusahaan high profile maupun low profile kegiatan pemecahan saham tidak mempengaruhi return saham tidak memberi kesejahteraan para pemegang sahamnya, hanya membagi saham menjadi lebih banyak. Hasil penelitian ini juga sesuai dengan penelitian yang dilakukan oleh Hanafie dan Diyani (2016) serta Rahayu dan Murti (2017) yang menyatakan bahwa tidak terdapat perbedaan yang signifikan pada return saham sebelum dan sesudah pengumuman stock split. Hal ini berarti stock split tidak memiliki pengaruh signifikan terhadap perubahan harga saham. 


\subsubsection{Abnormal Return Saham di Bursa Efek Indonesia Sesudah Stock Split pada Perusahaan High Profile dan Low Profile}

Dari hasil penelitian pada harga saham selama lima hari sebelum dan lima hari setelah stock split terhadap 16 perusahaan high profile dan 24 perusahaan low profile sebagai sampel. Secara keseluruhan dapat diketahui bahwa tidak terdapat perbedaan yang sangat signifikan pada abnormal return saham setelah stock split dari tahun 2016 sampai dengan 2018. Hal ini disebabkan karena pengumuman stock split dianggap tidak memiliki konten informasi yang penting bagi para investor dan pasar tidak bereaksi terhadap informasi stock split yang diberikan perusahaan, maka hal ini menyebabkan abnormal return tidak berpengaruh secara signifikan. Hal ini berarti, investor tidak terlalu memperhatikan mengenai tipe perusahaan baik high profile maupun low profile dalam memprediksi abnormal return saham dari perusahaan dan juga pengumuman stock split tidak memberikan informasi mengenai tingkat keuntungan di masa mendatang. Hasil penelitian ini juga sesuai dengan penelitian yang dilakukan oleh Satria dan Adnan (2018) serta Sakti dan Pangestuti (2013) yang menyatakan bahwa tidak terdapat perbedaan abnormal return sebelum dan sesudah peristiwa stock split serta pada perusahaan bertumbuh dan tidak bertumbuh tidak terdapat perbedaan abnormal return saham yang signifikan setelah pengumuman stock split.

\section{Kesimpulan dan Saran}

\subsection{Kesimpulan}

Berdasarkan hasil penelitian di atas, diperoleh kesimpulan sebagai berikut:

1. Terdapat perbedaan harga saham sebelum dan sesudah stock split pada perusahaan high profile. Hal ini dibuktikan dengan nilai asymp. sig (2-tailed) bernilai < 0,05 pada harga saham sebelum dan sesudah stock split di perusahaan high profile di Bursa Efek Indonesia yaitu sebesar 0,000 , maka terdapat perbedaan yang signifikan pada harga saham. Hipotesis pertama yang mengatakan terdapat perbedaan harga saham sebelum dan sesudah stock split pada perusahaan high profile diterima.

2. Terdapat perbedaan harga saham sebelum dan sesudah stock split pada perusahaan low profile. Hal ini dibuktikan dengan nilai asymp. sig (2-tailed) bernilai < 0,05 pada harga saham sebelum dan sesudah stock split di perusahaan low profile di Bursa Efek Indonesia yaitu sebesar 0,000 , maka terdapat perbedaan yang signifikan pada harga saham. Hipotesis kedua yang mengatakan terdapat perbedaan harga saham sebelum dan sesudah stock split pada perusahaan low profile diterima.

3. Terdapat perbedaan return saham sebelum dan sesudah stock split pada perusahaan high profile. Hal ini dibuktikan dengan nilai asymp. sig (2-tailed) bernilai < 0,05 pada return saham sebelum dan sesudah stock split di perusahaan high profile di Bursa Efek Indonesia yaitu sebesar 0,012 , maka terdapat perbedaan yang signifikan pada return saham. Hipotesis ketika yang mengatakan terdapat perbedaan return saham sebelum dan sesudah stock split pada perusahaan high profile diterima.

4. Tidak terdapat perbedaan return saham sebelum dan sesudah stock split pada perusahaan low profile. Hal ini dibuktikan dengan nilai asymp. sig (2-tailed) bernilai > 0,05 pada return saham sebelum dan sesudah stock split di perusahaan low profile di Bursa Efek Indonesia yaitu sebesar 0,257, maka tidak terdapat perbedaan yang signifikan pada return saham. Hipotesis keempat yang mengatakan terdapat perbedaan return saham sebelum dan sesudah stock split pada perusahaan low profile ditolak.

5. Tidak terdapat perbedaan abnormal return saham sebelum dan sesudah stock split pada perusahaan high profile. Hal ini dibuktikan dengan nilai asymp. sig (2-tailed) bernilai > 0,05 pada abnormal return sebelum dan sesudah stock split di perusahaan high profile di Bursa Efek Indonesia yaitu sebesar 0,086, maka tidak terdapat perbedaan yang

Pita Rahmawati et al., (Analisis Perbedaan Harga Saham, Return Saham, dan Abnormal Return

Sebelum dan Sesudah Stock Split pada Perusahaan High Profile dan Low Profile yang Terdaftar di 
signifikan pada abnormal return saham. Hipotesis kelima yang mengatakan terdapat perbedaan abnormal return saham sebelum dan sesudah stock split pada perusahaan high profile ditolak.

6. Tidak terdapat perbedaan abnormal return saham sebelum dan sesudah stock split pada perusahaan low profile. Hal ini dibuktikan dengan nilai asymp. sig (2-tailed) bernilai > 0,05 pada abnormal return sebelum dan sesudah stock split di perusahaan low profile di Bursa Efek Indonesia yaitu sebesar 0,652, maka tidak terdapat perbedaan yang signifikan pada abnormal return saham. Hipotesis keenam yang mengatakan terdapat perbedaan abnormal return saham sebelum dan sesudah stock split pada perusahaan low profile ditolak.

7. Terdapat perbedaan harga saham sesudah stock split pada perusahaan high profile dan low profile. Hal ini dibuktikan dengan nilai asymp. sig (2-tailed) bernilai $<0,05$ pada harga saham sesudah stock split di perusahaan high profile dan low profile di Bursa Efek Indonesia yaitu sebesar 0,000 , maka terdapat perbedaan yang signifikan pada harga saham. Hipotesis ketujuh yang mengatakan terdapat perbedaan harga saham sesudah stock split pada perusahaan high profile dan low profile diterima.

8. Tidak terdapat perbedaan return saham sesudah stock split pada perusahaan high profile dan low profile. Hal ini dibuktikan dengan nilai asymp. sig (2-tailed) bernilai > 0,05 pada return saham sesudah stock split di perusahaan high profile dan low profile di Bursa Efek Indonesia yaitu sebesar 0,314, maka tidak terdapat perbedaan yang signifikan pada return saham. Hipotesis kedelapan yang mengatakan terdapat perbedaan return saham sesudah stock split pada perusahaan high profile dan low profile ditolak.

9. Tidak terdapat perbedaan abnormal return sesudah stock split pada perusahaan high profile dan low profile. Hal ini dibuktikan dengan nilai asymp. sig (2-tailed) bernilai > 0,05 pada abnormal return saham sesudah stock split di perusahaan high profile dan low profile di Bursa Efek Indonesia yaitu sebesar 0,486, maka tidak terdapat perbedaan yang signifikan pada abnormal return saham. Hipotesis kesembilan yang mengatakan terdapat perbedaan abnormal return sesudah stock split pada perusahaan high profile dan low profile ditolak.

\subsection{Saran}

Berdasarkan penelitian di atas, saran yang dapat diberikan sebagai berikut:

1. Saran kepada investor melihat tidak adanya perbedaan yang signifikan baik pada return saham maupun abnormal return saham antara sebelum dan sesudah stock split, maka sebaiknya pihak investor tidak mengambil keputusan trading atau investasi jangka pendek supaya investasi saham yang dilakukan bisa lebih menguntungkan.

2. Saran bagi peneliti selanjutnya yaitu diharapkan untuk dapat menambah jumlah sampel sehingga akan mendapatkan hasil yang lebih akurat dan signifikan. Selain itu, peneliti selanjutnya diharapkan menggunakan model perhitungan lain dalam perhitungan abnormal return, serta menguji return saham pada perusahaan low profile sebelum dan sesudah stock split untuk mengetahui penyebab perusahaan tersebut tidak ada perbedaan return saham dibandingkan dengan perusahaan high profile.

\section{Daftar Pustaka}

Adliah, S. N., \& Nuzula, N. F. (2017). Analisis Abnormal Return dan Trading Volume Activity Sebelum dan Sesudah Stock Split (Studi pada Perusahaan Go Public 2014-2016). Jurnal Administrasi dan Bisnis, 49(1), 162-168. 
Azizah, F. Z. (2019). Abnormal Return dan Volume Perdagangan Saham Sebagai Reaksi Pasar terhadap Stock Split Emiten Consumer Goods di Indeks Saham Syariah Indonesia (ISSI) Periode 2015-2018. Doctoral Dissertation: Universitas Airlangga.

Budiyanti, E. (2011). Perkembangan Pasar Modal Dan Pertumbuhan Ekonomi Di Indonesia: Analisis Vector Autoregressions (VAR). Jurnal Ekonomi \& Kebijakan Publik, 2(2), 707-728.

Damayanti, N. L., Atmadja, A. T., SE, A., Darmawan, N. A. S., \& SE, A. (2014). Analisis Pengaruh Pemecahan Saham (Stock Split) Terhadap Tingkat Keuntungan (Return) Saham dan Likuiditas Saham (Studi Pada Perusahaan yang Go Public di Bursa Efek Indonesia Periode 2008-2013). JIMAT (Jurnal Ilmiah Mahasiswa Akuntansi) Undiksa, 2(1).

Diyana, N. (2008). Analisis Harga dan Volume Perdagangan Saham Sebelum dan Sesudah Stock Split (Event Study pada Perusahaan Manufaktur yang Melakukan Stock Split di Bursa Efek Indonesia pada periode 2004-2007). Tesis: Universitas Lambung Mangkurat Banjarmasin.

Ghozali, Imam. (2013). Aplikasi Analisis Multivariate dengan Program IBM SPSS. 21 Update PLS Regresi. Badan Penerbit Universitas Diponegoro.

Hanafie, Lukianto dan Diyani, Lucia Ari. (2016). Pengaruh Pengumuman Stock Split terhadap Return Saham, Abnormal Return dan Trading Volume Activity. Jurnal Bisnis dan Komunikasi, $3(2), 13-20$.

Hayat, Atma. (2008). Kajian tentang Perbedaan Harga Saham dan Volume Perdagangan Saham Sebelum dan Sesudah Pemecahan Saham pada Perusahaan Manufaktur yang Terdaftar di Bursa Efek Jakarta. Tesis: Universitas Lambung Mangkurat Banjarmasin.

Indarti, I. \& Purba, D. M. B. R.. (2011). Analisis Perbandingan Harga Saham dan Volume Perdagangan Saham Sebelum dan Sesudah Stock Split. Jurnal Ilmiah Aset, 13(1), 57-63.

Jogiyanto, Hartono. (2017). Teori Portofolio Dan Analisis Investasi. BPFE Yogyakarta.

Kohsaka, Y. (2014). The Japan Stock Split Bubble and the Livedoor Shock. International Journal of Economics and Finance Issues, 6(5), 33.

Kristianiarso, A. A. (2016). Analisis Perbedaan Likuiditas Saham, Harga Saham, dan Return Saham Sebelum dan Sesudah Stock Split (Studi Pada Perusahaan Go Public yang Melakukan Stock Split Periode 2011-2014). Doctoral Dissertation: Universitas Mercu Buana.

Kurniawati, Indah. (2003). Analisa Kandungan Informasi Stock Split dan Likuiditas Saham: Studi Empiris pada Non-Sychronous Trading. The Indonesian Journal of Accounting Research, 6(3).

Ijak, M. T. (2018). Analisis Pengaruh Stock Split terhadap Harga Saham dan Volume Perdagangan Saham pada Perusahaan Go Public di Bursa Efek Indonesia. Doctoral Dissertation: STIE Perbanas Surabaya.

Prisillia, D. (2017). Analisis Likuiditas dan Return Saham Sebelum dan Sesudah Stock Split: Studi Kasus pada Perusahaan yang Terdaftar Di Bursa Efek Indonesia. UNPAR Institutional

Pita Rahmawati et al., (Analisis Perbedaan Harga Saham, Return Saham, dan Abnormal Return

Sebelum dan Sesudah Stock Split pada Perusahaan High Profile dan Low Profile yang Terdaftar di

Bursa Efek Indonesia) 
Repository.

Rahayu, D., \& Murti, W. (2017). Pengaruh Pemecahan Saham (Stock Split) terhadap Return Saham, Bid-Ask Spread dan Trading Volume Activity pada Perusahaan yang Terdaftar di Bursa Efek Indonesia Periode Tahun 2009-2013. Jurnal Akuntansi Fakultas Ekonomi, 11(1).

Rahayu, I. R. (2006). Reaksi Pasar terhadap Peristiwa Stock Split yang Terjadi di Bursa Efek Jakarta (BEJ). Skripsi: Universitas Islam Indonesia Yogyakarta.

Royana, E. (2008). Analisis Harga dan Volume Perdagangan Saham Sebelum dan Sesudah Stock Split (Event Study pada Perusahaan yang Melakukan Stock Split di Bursa Efek Jakarta pada Periode 2004-2006). Tesis: Universitas Lambung Mangkurat Banjarmasin.

Rusliati, E., \& Farida, E. N. (2010). Pemecahan Saham terhadap Likuiditas dan Return Saham. Jurnal Bisnis dan Akuntansi, 12(3), 161-174.

Sadikin, A. (2016). Analisis Abnormal Return Saham Dan Volume Perdagangan Saham Sebelum Dan Sesudah Peristiwa Pemecahan Saham (Studi Pada Perusahaan Yang Go Public Di Bursa Efek Indonesia. Jurnal Manajemen dan Akuntansi, 12(1).

Sakti, P. O., \& Pangestuti, I. R. D.. (2013). Analisis Pengaruh Stock Split terhadap Abnormal Return dan Volume Perdagangan Saham pada Perusahaan Bertumbuh dan Tidak Bertumbuh (Studi Kasus pada Bursa Efek Indonesia 2008-2012). Doctoral dissertation, Fakultas Ekonomika dan Bisnis.

Sari, R. A. (2012). Pengaruh Karakteristik terhadap Corporate Social Responsibility Disclosure pada Perusahaan Manufaktur yang Terdaftar di Bursa Efek Indonesia. Nominal: Barometer Riset Akuntansi dan Manajemen, 1(2), 124-140.

Satria, K., \& Adnan, A. (2018). Analisis Peristiwa Stock Split terhadap Harga Saham, Likuiditas Saham dan Abnormal Return (Studi Kasus pada Perusahaan Manufaktur yang Terdapat di Bursa Efek Indonesia Tahun 2011-2015). Jurnal Ilmiah Mahasiswa Ekonomi Akuntansi, 3(3), 364-384.

Shofa, I., \& Utiyati, S. (2016). Analisis Perbandingan Harga Dan Volume Perdagangan Saham Sebelum Dan Sesudah Stock Split. Jurnal Ilmu dan Riset Manajemen (JIRM), 5(7).

Sugiyono. (2013). Metode Penelitian Pendidikan Pendekatan Kuantitatif,. Kualitatif, dan R\&D. Alfabeta.

Susianti, T. (2020). Analisis Dampak Pemecahan Saham (Stock Split) terhadap Trading Volume Activity dan Abnormal Return Ssaham yang Termasuk dalam Daftar Efek Syariah Tahun 2013-2017. VOLATILITAS, 2(2).

Urmila, N. M. D., \& Mertha, I. M. (2017). Tipe Perusahaan Memoderasi Ukuran Perusahaan, Profitabilitas, Kepemilikan Asing pada Pengungkapan CSR Perusahaan Manufaktur Di BEI. E-Jurnal Akuntansi, 19(3), 2145-2174.

Utami, Komang Ayu Seniari dan Ulupui, I Gusti Ketut Agung. (2013). Reaksi Pasar Atas Pengumuman Pemecahan Saham pada Perusahaan LQ45 dan NonL Q45. Skripsi: Universitas Udayana. 
Wijanarko, I., \& Prasetiono, P. (2012). Analisis Pengaruh Pemecahan Saham (Stock Split) Terhadap Likuiditas Saham Dan Return Saham (Studi Kasus Pada Perusahaan Yang Terdaftar BEI Periode 2007-2011). Doctoral Dissertation: Fakultas Ekonomika dan Bisnis.

Yulia, A., \& Afrianti, A. (2014). Analisis Perbedaan Pengungkapan Corporate Social Responsibility pada Perusahaan High dan Low Profile (Studi Empiris Perusahaan Manufaktur yang Terdaftar di BEI). Jurnal Dinamika Akuntansi dan Bisnis, 1(1), 92-206. 